\title{
The Chemistry of Famine: Nutritional Controversies and the Irish Famine, c.1845-7
}

\author{
IAN MILLER* \\ Centre for the History of Medicine in Ireland, School of History and Archives, \\ University College Dublin, Belfield, Dublin 4, Ireland
}

\begin{abstract}
The activities of Irish medical practitioners in relieving the impact of the Irish Famine (c.1845-52) have been well documented. However, analysis of the function of contemporary medico-scientific ideas relating to food has remained mostly absent from Famine historiography. This is surprising, given the burgeoning influence of Liebigian chemistry and the rising social prominence of nutritional science in the 1840s. Within this article, I argue that the Famine opened up avenues for advocates of the social value of nutritional science to engage with politico-economic discussion regarding Irish dietary, social and economic transformation. Nutritional science was prominent within the activities of the Scientific Commission, the Central Board of Health and in debates regarding soup kitchen schemes. However, the practical inefficacy of many scientific suggestions resulted in public associations being forged between nutritional science and the inefficiencies of state relief policy, whilst emergent tensions between the state, science and the public encouraged scientists in Ireland to gradually distance themselves from state-sponsored relief practices.
\end{abstract}

Keywords: Great Famine, Medical History of Ireland, History of Nutrition, History of Dietetics, History of Digestion

\begin{abstract}
Article
The Potato Commission did not effect much good, although it was said thirteen thousand pounds were expended upon the inquiry - an extravagance which very much annoyed the doctors, who only got five shillings a day without meat or drink. . . for doctoring a hundred or two starving wretches in typhus fever. The chemists then took up the question, and found that there was too much phosphorus in one description of food, and too much sulphur in another, and too much or too little lime in a third; and, in fine, that, with few exceptions, man could not live on bread alone. Then the fact became evident to the chemists, which had long ago been practically demonstrated by the people, that the potato, bad as it was, contained more

* Email address for correspondence: ian.miller2@ucd.ie

This research was kindly supported by the Irish Research Council. I wish to thank Catherine Cox, Alice Mauger and Christopher Hamlin for their feedback, criticism and useful suggestions with regards to this article, as well as with the wider project from which this research stems. Early versions of this article were presented at 'Health in History: The Eightieth Anglo-American Conference' held at the Institute of Historical Research, University of London, July 2011 and the 'Centre for the History of Medicine in Ireland' conference held at the University of Ulster, May 2011. I would like to thank those audience members whose feedback and comments helped to shape this article.
\end{abstract}


life-sustaining elements, added to more palatable qualities, and less deleterious constituents, when taken for any length of time into the system, than any other vegetable that could be procured. ${ }^{1}$

Penned in 1854 by prestigious Dublin surgeon William Wilde, this critique suggests that ideas derived from contemporary nutritional science helped to structure how medicoscientific communities responded to the failure of the potato crop during the Irish Famine (c.1845-52). The day-to-day activities of medical men have been well documented within the voluminous Famine historiography. ${ }^{2}$ Yet Wilde's statement also points to the existence of a pervasive web of ideas which shaped understandings of Irish dietary habits, and informed medico-scientific efforts to comprehend the catastrophe. Notably, Wilde records the apparent failure of scientific knowledge to perform successfully and efficiently as a component of relief policy. Even Wilde - a highly influential medical figure whose research into ophthalmology and ear diseases had earned him an international reputation - retained scepticism towards the practical utility of nutritional theory within official relief mechanisms, a stance which reveals an inherent turbulence in the interaction between science, medicine and politics during the Famine. According to Wilde's account, scientific speculation had proven to be of limited practical value as a state tool, merely reiterating forms of knowledge - in a language steeped in the technicalities of professional analysis - already intuitively known by the Irish peasantry through day-to-day experience.

However, Wilde's critique was formulated retrospectively. In fact, as his statement reveals, chemical analysis had been allocated a privileged position within state-organised schemes at the commencement of the Famine, providing a conceptual backdrop to the activities of scientific men dispatched to investigate the blight. His statement raises various questions. Firstly, why was such a degree of faith and optimism attached to chemical science at this particular historical juncture in relation to the Famine? James Vernon has persuasively argued that the hungry and starving began to be transformed into figures deemed worthy of humanitarian concern during the $1840 \mathrm{~s}^{3}{ }^{3}$ Yet Vernon identifies scientific intervention into hunger as occurring in much later decades, whereas Wilde's critique contrarily identifies scientific efforts to relieve potential starvation as significant in the 1840s. ${ }^{4}$ Secondly, why did the application of this scientific knowledge seemingly fail to resolve Famine-related problems, and what impact did this have upon Irish public perceptions of nutritional science? Jan Golinski has remarked upon the historicity of gulfs between the production of scientific knowledge and its interpretation by the public who, at worst, condemn science as a source of authority and a tool of powerful social interests, and this scenario is in many ways affirmed by Wilde's statement. ${ }^{5}$ Within this article I argue that strong links were forged between nutritional science and state-sponsored relief practices during the opening years of the Famine. Yet the relationship between science, the

\footnotetext{
${ }^{1}$ William Wilde, 'The Food of the Irish', Dublin University Magazine, 43 (1854), 127-46: 138.

${ }^{2}$ Recent texts include E. Margaret Crawford, 'Scurvy in Ireland during the Great Famine', Social History of Medicine, 1 (1988), 281-300; Peter Froggatt, 'The response of the medical profession to the Great Famine', in E. Margaret Crawford (ed.), Famine: The Irish Experience 900-1900: Subsistence Crises and Famines in Ireland (Edinburgh: John Donald, 1989), 134-56; Laurence M. Geary, 'Famine, fever and the bloody flux', in Cathal Póirtéir (ed.), The Great Irish Famine (Cork: Mercier Press in association with Radio Telefis Éireann, 1995), 74-85; Laurence M. Geary, “The last disastrous epidemic”: medical relief and the Great Famine', in Chris Morash and Richard Hayes (eds), Fearful Realities: New Perspectives on the Famine (Dublin and Portland, OR: Irish Academic Press, 1996), 49-59.

3 James Vernon, Hunger: A History (Cambridge, MA and London: Belknap Press, 2007), 2.

${ }^{4}$ Ibid., 81-117.

5 Jan Golinski, Science as Public Culture: Chemistry and Enlightenment in Britain, 1760-1820 (Cambridge: Cambridge University Press, 1992), 2.
} 
state and the public was intricate and precarious, so much so that scientific intervention sparked widespread debates which reached an apex during the soup kitchen controversies of 1847. Hence, nutritional science's stance during the Famine became remarkably fluid and shifting as governmental policy evolved between 1845 and 1847.

In doing so, I aim to draw attention to the complexities of food reform in mid-century Ireland. Nineteenth-century Irish historiography often depicts the dramatic dietary changes that followed the Famine as having emerged as a natural response to the harrowing lessons learnt between 1845 and 1852 on over-relying upon one crop alone. This article, and the wider body of research from which it stems, reveals how the issue of dietary reform was far more intricate, and that discussion of it was embedded within wider international developments in medical science and nutritional thinking. Food reveals itself as a subject that offers wider insights into the tense relationships between medicine, science, government agencies and the Irish public in this period. Governmental interest in harnessing nutritional knowledge also demonstrates an early experiment in investigating and regulating the diet of citizens, the likes of which tended not to be seen again until the early twentieth century.

\section{Ireland, the Potato and Science}

In 1845 , an estimated $40 \%$ of the Irish population subsisted principally upon the potato, typically consuming the crop with buttermilk, water, fish or whiskey. ${ }^{6}$ Prior to the Famine, critical commentary on this mono-crop existence was rife, and tended to focus upon its detrimental impact upon Ireland's socio-economic structure. ${ }^{7}$ Condemnation of the crop's widespread usage permeated English perceptions of Ireland, while the issue of food remained closely intertwined with wider debates regarding Irish socioeconomic underdevelopment. The potato became critically derided as a remarkably easy crop to produce; this observation was applied to justify prevailing stereotypes of the Irish peasantry as inherently idle. Easy cultivation meant less time working on the fields, so influential political economists insisted, thereby promoting over-population and further poverty as Irish peasants allegedly chose to spend their excess spare time procreating. ${ }^{8}$ Ending reliance upon the potato thus became central to politico-economic debates regarding the need to stabilise Irish society, rear the country's inhabitants into modernity and promote moral values of restraint (dietary or otherwise). Even outside the level of abstract economic theory, the potato was prone to frequent failures, a problem compounded by a lack of alternative foodstuffs being available to counter communal starvation. Poor nationwide harvests were witnessed in 1740-1, 1800-1, 1816-18, 1822 and 1831, while partial, regional potato scarcities were common in intermittent years. ${ }^{9}$ Yet this was a period when an established framework for considering diet from a nutritional perspective was in a nascent state, and it is unsurprising to find that the health advantages or disadvantages of the potato remained undocumented. Nonetheless, a broad consensus

\footnotetext{
${ }^{6}$ Leslie A. Clarkson and Elizabeth M. Crawford, Feast and Famine: Food and Nutrition in Ireland, 1500-2000 (Oxford: Oxford University Press, 2001), 59-87.

${ }^{7}$ Cormac Ó Gráda, Ireland before and after the Famine: Explorations in Economic History (Manchester and New York: Manchester University Press, 1993), 1-97.

${ }^{8}$ Peter Gray, Famine, Land and Politics: British Government and Irish Society 1843-1850 (Dublin and Portland, OR: Irish Academic Press, 1999), 4-9.

${ }^{9}$ Ó Gráda, op. cit. (note 7), 2-8.
} 
existed which foresaw dietary transformation as a mechanism with which to assist in resolving immediate and long-term problems in Ireland's social infrastructure. ${ }^{10}$

Why, then, had confidence in dietary change being guided by scientific expertise gained currency by 1845 ? In part, this can be ascribed to the gradual development of refined, nuanced models of consumption during the early nineteenth century. During this period, important shifts in food analysis occurred which partially transformed diet into a 'medicalised' issue. Traditional approaches to consuming had typically posited the relationship between food and the individual as being determined by constitution. Hence, discussion of dietetic health had tended to devote less attention to understanding the properties of individual foodstuffs, as the manner by which food was assimilated into bodily systems was seen as differing from person to person and being influenced by a diverse range of factors.

Yet, during the nineteenth century food intake became subject to closer analytical scrutiny. Initially, attention remained focused on understanding how the inner body reacted to ingested food rather than on analysing food content. Accordingly, the physiology of digestion captured the attention of a wide range of medical investigators. ${ }^{11}$ Physicians, pathological anatomists and physiologists speculated widely on the manner by which food was taken into the bodily system, assimilated into the blood and passed into the tissues. Numerous investigators explored the mastication of food, its admixture with saliva, its digestion by the stomach's muscular powers, how it was propelled into the bowels, and then carried into the blood or transformed into excrementitious matter. ${ }^{12}$ New norms of healthy digestion were established, with physiological deviation from these being increasingly referred to as indigestion or dyspepsia. Methods of chewing, stomach sizes, the ideal time which the body spent digesting, and so on, all became closely analysed by emerging regimes of internal exploration. ${ }^{13}$

Given the unique nature of Irish dietary customs, it is unsurprising to find the Irish agricultural labourer gradually falling under the gaze of digestive analysis. A burgeoning interest in Irish dietary customs accumulated in the early 1840s when firm distinctions became mapped between normative models of digestion and Irish dietary realities. A sense of alarm became attached to the large quantities of potatoes consumed in Ireland, a tradition seen as clashing profoundly with the ideals of a burgeoning dietetic science that venerated dietary restraint. ${ }^{14}$ High levels of attention were awarded to this subject within Derry-born physician James Johnson's popular A Tour of Ireland (1844), for instance. Although best remembered for attending the Duke of Clarence and editing the MedicoChirurgical Review, Johnson also published a series of influential works on digestion. It was perhaps Johnson's interest in ascertaining the workings of the stomach, combined with his Irish background, which fostered his interest in the relationship between physiology

\footnotetext{
${ }^{10}$ Christine Kinealy, This Great Calamity: The Irish Famine, 1845-52 (Dublin: Gill and Macmillan, 1994, [2006]), 1-3.

${ }^{11}$ Ian Miller, A Modern History of the Stomach: Gastric Illness, Medicine and British Society, 1800-1950 (London: Pickering and Chatto, 2011), 11-38.

${ }^{12}$ See, for instance, William Beaumont, Experiments and Observations on the Gastric Juice and the Physiology of Digestion (Plattsburgh: F.P. Allen, 1833).

${ }^{13}$ Representative texts include John Abernethy, Surgical Observations on the Constitutional Origin and Treatment of Local Diseases (London: Longman, Hurst, Reese and Orme, 1809); John A. Paris, A Treatise on Diet (London: Thomas and George Underwood, 1826); James Johnson, An Essay on Morbid Sensibility of the Stomach and Bowels (London: 1827); Andrew Combe, The Physiology of Digestion (Edinburgh: MacLachlan and Stewart, 1836).

${ }^{14}$ Miller, op. cit. (note 11), 11-38.
} 
and Ireland's mono-crop culture. ${ }^{15}$ Within his A Tour of Ireland (1844), Johnson expressed bewilderment at the widespread habit of only half-boiling potatoes, so that the centre remained so solid that it became commonly referred to as the 'bone of the potatoe'. This custom no doubt made sense to the Irish peasant as it allayed hunger for longer, but it fitted uneasily with contemporary discourse on digestion. Hence, in his text, Johnson proclaimed that 'there is scarcely a more indigestible substance taken into the human stomach than a half-boiled potatoe; and, to, a moderately dyspeptic Englishman - such diet would be less than poison'. ${ }^{16}$

Alarmingly, in a cultural milieu informed by industrial advancement and productivity, Johnson implicated widespread reliance upon potato consumption as maintaining wide segments of the Irish populace in a realm akin to primitive culture. By relying upon simplistic modes of food cultivation, the Irish peasant was depicted as perpetuating an agricultural system that proved detrimental to Ireland's progression into social modernity. Johnson's unabashed views regarding Irish cultural primitivism reached a notable climax when he attributed popular belief in fairies, goblins, daemons and kelpies to gastric phenomena. For him, the stomach and digestive organs constituted a rich epicentre of nerves from which, through 'gastric sympathy' and internal nervous connections, abdominal problems might present themselves in other parts of the body - in this instance in the mind. ${ }^{17}$ This model allowed Johnson to ascribe the sightings of fantastical creatures to the potato diet, and to argue that indigestion, stimulated by excessive levels of poteen and potatoes, created vivid nightmares later recollected as actual sightings. ${ }^{18}$

Johnson's arguments were imbued with a sense that the British stomach was a far healthier organ than its Irish equivalent, while the deviant composition of Irish digestive physiology provided him with an explanatory factor for Irish cultural backwardness. In Johnson's view, the impact of the country's economic system had become metaphorically, and literally, inscribed onto the peasant's internal organs. This stance allowed for the tracing of the evolution of a nation of 'potato people' apparently possessing abnormally large stomachs. Overall, inappropriate dietary arrangements among large sections of the Irish populace became presented as bearing implications that extended far beyond the corporeal realm, contributing significantly to adverse socio-economic conditions. Certainly, Johnson's depictions served little purpose in terms of disseminating health advice. Instead, his physiological models were intended to add weight to wider political and economic debates regarding how best to stabilise and modernise Irish society, which is suggestive that medical opinion, in this instance, was willing to position itself as compatible with politico-economic agendas.

Literature such as Johnson's undoubtedly influenced the perspectives of non-medical writers such as Thomas Campbell Foster who claimed in the early 1840s that the Irish populace had a natural craving for large quantities of food. Potatoes, so Foster asserted, contain very little nourishment meaning that large amounts needed to be consumed if the instinctive requirements of the bodily system were to be fulfilled. Yet by perpetually subsisting on excessive food quantities, the Irish peasant's stomach seemed to have become engorged, constantly craving quantity. In his text, Foster even claimed that physiological investigation had proven the stomach of the potato-fed Irish peasant to be

\footnotetext{
15 Johnson, op. cit. (note 13).

16 James Johnson, A Tour in Ireland (London: S. Highley, 1844), 313.

17 Miller, op. cit. (note 11), 11-38.

18 Johnson, op. cit. (note 16), 311-2.
} 
double the size of the average stomach, although his source for this weighty claim remains elusive. ${ }^{19}$ In Foster's example, as with Johnson's, the concept of communal abnormal digestion provided a trope which in many ways affirmed contemporary impressions of a seemingly superior British culture by articulating profound difference between centralised cultures and peripheral subjects. Foster drew heavily upon visions of a normative digestive system which rendered that of the Irish peasant as essentially pathological - an allegoric device intended to denote social primitivism and cultural backwardness. Tellingly, when not penning travel literature, Foster regularly contributed to The Times, a newspaper which persistently promulgated unsympathetic attitudes to Irish poverty by placing blame for it upon Irish idleness. Hence, Foster's observations of the internal bodily workings of the Irish peasant formed part of a wider agenda of promoting Irish socio-economic reform.

These writings reveal how physiological ideas might be adapted to suit political and economic ends while perpetuating pre-existing racial presumptions. Yet, as a tool, digestive physiology was less useful for suggesting what crops might replace the potato in order to effect the elusive goal of Irish dietary reform. However, the varieties of nutritional science which developed from the 1830s employed a radically different approach, taking food itself as an analytical starting point rather than physiological reactions to it. Internationally renowned German chemist Justus von Liebig was particularly successful in impressing upon the public the premise that findings derived from chemistry contain social, economic and political utility if applied appropriately. ${ }^{20} \mathrm{By}$ analysing the contents of a range of foodstuffs, Liebig deciphered a comprehensive list of which chemicals enter the body during digestion, placing himself in an authoritative position to advise on consumption. Liebig explained physiological phenomenon as chemical in nature, speculating that all organic nitrogenous constituents are derived from plant proteins. Within his work on animal chemistry, for instance, he described blood as being composed in part of fibrin and albumin, while protein was determined as produced within vegetables which, when ingested, strengthened flesh and cellular tissue. The idea that chemical transformations occur following ingestion, and that foodstuffs are best chosen with this in mind, formed one of Liebig's most inspiring contributions to an already rich international literature on diet. ${ }^{21} \mathrm{He}$ constructed a model of consumption that proved attentive to food articles and their components while simultaneously producing research findings which were potentially socially applicable during the 'hungry '40s'. And, as others have noted, the impact of Liebig's research upon discussion of diet was profound in subsequent decades, stimulating new approaches to everyday dietary matters. ${ }^{22}$

Hence, by the eve of the Famine a strong intellectual framework had evolved which explained food intake and nutrition scientifically. Meanwhile, chemistry was being presented as a socially beneficial force, and scientific cookery as a useful civilising agent. ${ }^{23}$ As Adelman has persuasively argued, in Ireland during the 1840 s science became

\footnotetext{
19 Thomas C. Foster, Letters on the Condition of the People of Ireland (London: Chapman and Hall, 1846), $558-9$.

${ }^{20}$ William H. Brock, Justus von Liebig: The Chemical Gatekeeper (Cambridge: Cambridge University Press, 1997), 176.

${ }^{21}$ Justus von Liebig, Research on the Chemistry of Food, trans. William Gregory (Lowell: Daniel Bixby and Company, 1848).

${ }^{22}$ Mark R. Finlay, 'Early marketing and the theory of nutrition: the science and culture of Liebig's extract of meat', in Harmke Kamminga and Andrew Cunningham (eds), The Science and Culture of Nutrition, 1840-1940 (Amsterdam: Rodopi, 1995), 48-74.

${ }^{23}$ Ibid., 48-9.
} 
particularly valued as a discourse by a government eager to embrace and promote it as a means of effecting socio-economic reform. ${ }^{24}$ Contemporaneously, as Vernon has demonstrated, starvation became an increasingly emotive issue during this decade, and one which governments found increasingly harder to justify using Malthusian logic. ${ }^{25}$ Hence, starvation gradually transformed into an issue that fell under the aegis of governmental responsibility while organic chemistry increasingly presented itself as a socially transformative tool with the potential to assist in this process.

It is in these contexts that proponents of food chemistry became well positioned to exert an intellectual and practical influence within state-managed relief practice, and to occupy a socially influential space in Famine-period Ireland. In 1845, potato yields were $33 \%$ less than in previous years, and in $184675 \%$ less. By 'Black '47', potato acreage had fallen from over two million acres to only $284000 .^{26}$ This opened up opportunities for inclined medico-scientific figures to apply understandings of dietary intake to resolve, or at best relieve, the ramifications of blight. Importantly, given the prevalence of presumptions that the Irish populace would seek alternative food sources once famine receded, Ireland presented a remarkably suitable terrain upon which nutritional science's social claims could be tested, imposed and proven on a populace presumed to be eager to alter its dietary traditions.

\section{Salvaging Potatoes}

From the outset, chemical theories dominated understandings of the Famine. In October 1845, Prime Minister Robert Peel established a Scientific Commission to ascertain the cause of crop failure and to formulate solutions. Historians have frequently observed how this group were mistaken in their conclusions on the cause of the blight, which was only established as fungal in the 1890s. ${ }^{27}$ Ó Murchadha, for instance, has recently argued that the Commission's members were hampered by a lack of expertise in plant biology, and passes judgement upon them for ignoring suggestions of the blight's fungal origins. ${ }^{28}$ Yet this perspective is retrospective, relying upon hindsight, and ultimately fails to assess why the Commission chose the path which they did. To simply state that historical opinions were inaccurate does not explain why speculation on the blight's chemical origin became privileged over fungal explanations. Fungal theories had certainly been developed, and remedies to exterminate fungi involving the application of acids, alkaline liquors and chlorine were well circulated. ${ }^{29}$ Yet chemistry was a more developed discipline in the 1840 s, and more socially active. Certainly, the composition of the Commission reveals the confidence placed in this branch of scientific activity by Peel. The Commission was made up of a group who subscribed to and promulgated contemporary confidence in organic chemistry. Lyon Playfair was a Scottish Professor of Chemistry at the Royal Manchester

\footnotetext{
24 Juliana Adelman, Communities of Science in Nineteenth-Century Ireland (London: Pickering and Chatto, 2009), 1-5. See also Edward G. Lengel, The Irish Through British Eyes: Perceptions of Ireland in the Famine Era (London and Westport, CT: Praeger, 2002).

25 Vernon, op. cit. (note 3), 18-21.

${ }^{26}$ Clarkson and Crawford, op. cit. (note 6), 88.

27 Christina Matta, 'Spontaneous Generation and Disease Causation: Anton de Bary's Experiments with Phytophthora infestans and Late Blight of Potato', Journal of the History of Biology, 43 (2010), 459-91.

28 Ciarán Ó Murchadha, Great Famine: Ireland's Agony, 1845-52 (London: Continuum International Publishing Group, 2011), 34.

29 Thomas P. O'Neill, 'The Scientific Investigation of the Failure of the Potato Crop in Ireland 1845-6', Irish Historical Studies, 5 (1946), 123-38.
} 
Institution; John Lindley was an accomplished English botanist; and Robert Kane was the President of Queen's College, Cork. ${ }^{30}$ An often un-noted but significant point about the Commission is that Playfair was a former pupil of Liebig. ${ }^{31}$ Kane, meanwhile, had also studied organic chemistry in Giessen under Liebig, and had made important attempts to encourage the adoption of Liebigian principles in Ireland. ${ }^{32}$ Given this weighty Liebigian influence, it is unsurprising that the Commission's activities focused so intently upon the chemistry of famine, and that its members were disinclined to explore suggestions running counter to their professional presuppositions. ${ }^{33}$

Peel established the Scientific Commission shortly after the publication of George Phillips' The Potato Disease: Its Origin, Nature and Prevention. Phillips had gained prominence as a highly active member of the London Chemical Society, being well respected in political circles for his scientific prowess. In 1842, he had established a chemical laboratory to help enforce the Pure Tobacco Act, an activity which underlined the official confidence placed in chemistry. ${ }^{34}$ Phillips' work presented the fullest elucidation of the potato as a target of scientific scrutiny published in the UK so far, and stimulated a chemical reimagining of the potato. Within it, the potato emerged as an object analysed and divided into its constituent parts: water, starch, sugar, potateine, gum, albumen, ligneous fibre, silica, alumina, lime, potash, magnesia and so on. These highly specific elements were depicted as not only contributing to the overall constitution of the potato, but also as individually serving particular purposes within the human system. The potato's tuber, meanwhile, became reconstituted as a cellular tissue filled with granules of starch floating in water, gum, sugar and albumen. Importantly, Philips' analysis of the potato suggested that the crop was in fact a highly useful food article containing all of the essential constituents of healthy digestion and nutrition: starch, gum, sugar and albumen, providing the body with a healthy supply of carbon, oxygen, hydrogen and nitrogen.

In his work, Phillips closely delineated a transformation from healthy to diseased potato. Gradually decreasing levels of sugar, potateine, gum, albumen and ligneous fibre were hypothesised as resulting from blight, whilst a subtle transformation from healthiness to rottenness was mapped involving the decomposition of albumen, the colouring of the potato with oxygen, the browning of the diseased crop with alkalis, the consistency of the potato shifting from acid to alkali and ammonia being produced by putrid fermentation. Phillips concluded that rain was the primary cause of these chemical alterations, explaining that excess moisture had encouraged the formation of an surplus of pendulums and tubers that had ceased to be supplied with nutriment once the rain had prostrated the crop's powers. Newly formed pendulums and tubers were thus left unsupported by the plant, causing the living principle to cease to exist and chemical processes of decomposition to begin. Overall, rain and moisture had stimulated the crop beyond its ability, overpowering it and producing putrefaction. ${ }^{35}$

\footnotetext{
30 James S. Donnelly JR., 'Famine and government response 1845-6', in William E. Vaughan (ed.), A New History of Ireland V: Ireland under the Union I, 1801-70 (Oxford: Clarendon Press, 1989), 272-85: 274.

${ }^{31}$ Brock, op. cit. (note 20), 183.

${ }^{32}$ Robert Kane, The Industrial Resources of Ireland (Dublin: Hodges and Smith, 1844); Clara Cullen, C., 'The Museum of Irish Industry (1845-1867): research environment, popular museum and community of learning in mid-Victorian Ireland' (unpublished PhD thesis, University College Dublin, 2008).

33 O’Neill, op. cit. (note 31).

${ }^{34}$ Noel G. Coley, 'Medical Chemists and the Origins of Clinical Chemistry in Britain (circa 1750-1850)', Clinical Chemistry, 50 (2004), 961-72.

35 George Phillips, The Potato Disease: Its Origin, Nature and Prevention (London: S. Highley, 1845).
} 
The influence of Phillips' chemical paradigms became visibly clear in the Commission's initial suggestions that nutritional elements could be salvaged from diseased potatoes. This plan was rendered possible by the pervasiveness of theoretical frameworks which conceptualised the potato as a crop divisible into constituent chemical elements. Kane felt confident that the starch content of diseased potatoes could be salvaged but maintained that extracted starch could never substitute the potato itself, as the crop also contained other substances necessary to support human life. ${ }^{36}$ A practical, cost-efficient solution proposed involved educating the Irish poor on how to produce starch at home, an approach resting on presumptions that the techniques of chemistry could be imitated in domestic settings. ${ }^{37}$ Notably, this approach entailed minimal official intervention, thereby satisfying prevailing principles of laissez-faire intervention. The Commission's instructions for this process were, however, complex to say the least. A rasp or grater was to be made by punctuating a sheet of tin or iron with holes. The pulp produced from grating should then be drenched with water, and the remaining pulp and starch separated. The pulp was then to be dried on a griddle over a fire, and put aside, whilst wet lumps of starch could be dried on a shelf for a number of days. The Irish peasantry were informed through leaflets, posters and talks given in churches that wholesome bread could be made by mixing starch and pulp with peas-meal, bean-meal, oatmeal or flour. ${ }^{38}$

Ultimately, however, the dispersion of such complex advice accentuated public perceptions of rifts between scientific theory and social practice, while the apparent collusion of state and science in producing inefficient advice did little to bolster nutritional science's public image in Ireland. Sporadic evidence exists of localised enthusiasm for the Commission's remedies. In October 1845, for instance, Henry John Porter, land agent to the Duke of Manchester of Tanderagee, Co. Kildare, held meetings at the school houses on his estate to instigate the domestic conversion of potatoes. ${ }^{39}$ Yet, to critical observers, such advice seemed to be of little value, a predicament which provoked widespread condemnation from various actors across the Irish social spectrum. The Commission persisted in disseminating advice despite an influx of letters sent to them and the Famine Relief Commissioners lamenting the impracticality of starch production. ${ }^{40}$ Some of these implicated peasant culture as a restrictive factor. Reverend Edward Hoare of Ballymore, Co. Kildare, for instance, wrote to the Commission expressing doubts about persuading the peasantry to implement their recommendations. ${ }^{41}$ A paper read to the Natural History Society of Dublin in December, meanwhile, envisaged problems with starch production as residing in 'the apathy and indifference of the peasantry' who were reported to show a tendency to dislike innovations in methods of storing their potatoes. Peasants, it was claimed, did 'not look much beyond the present hour' and, in any case, were under the belief that public funds would become available to cover their loss. ${ }^{42}$

Other critical voices saw problems with implementation as residing more in financial considerations than peasant conservatism or apathy. Letters sent to the Commission

\footnotetext{
36 Nation, 1 November 1845, 36.

${ }^{37}$ National Archives of Ireland (hereafter NAI), Relief Commission Papers (hereafter RLFC) 3/1/78-86; RLFC3/1/319; RLFC3/1/998; RLFC3/1/1935; RLFC3/1/3417.

38 Nation, 8 November $1845,54$.

39 NAI, RLFC2/Z14466.

40 NAI, RLFC2/Z155668.

41 NAI, RLFC2/Z15556.

42 O'B. Bellingham, 'Observations upon the Potato Disease as it Prevailed in Ireland this Year', Dublin Medical Press, 13 (1845), 359-64: 364.
} 
and the Relief Commissioners demonstrate the prevalence of opinions that the former were oblivious to the Irish peasantry's financial situation. One of these stressed that cottiers could not afford the lime suggested as useful to dry potatoes with. ${ }^{43}$ Similarly, Reverend William Fisher, rector of Killmore, Co. Cork, estimated that 2500 peasants in his parish could not afford to purchase the oatmeal recommended as a mixer for starch, adding that financial aid would be more appropriate. ${ }^{44}$ Others expressed indignation at Irish corn exports not being prohibited, a seemingly more practical solution than encouraging the peasantry to apply complex processes of potato conversion. ${ }^{45}$ On a subtextual level, these conflicting accounts of peasant conservatism and calls for financial support represented far wider cultural debates regarding preferences for self-help or state intervention. Underpinning discussion of financial aid were strong implications that Ireland was deserving of state support, and that a system of scientifically guided starch production reliant upon self-initiative was impractical.

The existence of intra-professional disputes also undermined public confidence in officially sanctioned scientific suggestions. Edward Carroll, agricultural superintendent on the estates of William Wrexon Beecher, Mallow, Co. Cork and member of the Royal Agricultural Society of Ireland, wrote to the Freeman's Journal in October declaring official scientific advice on potato conversion as a collection of 'silly nostrums' created by men who 'knew little of practice applicable to the circumstances of this country'. Accordingly, he condemned Kane's idea of drying potatoes in the open air on the basis that Ireland's weather, especially in autumn, was such that barely two days passed without rain. Carroll also lamented the Commission's advice that potatoes should be dried in uninhabited rooms, as most small Irish labourers did not have the luxury of space in their huts. ${ }^{46}$ Although Carroll's statements indicate some degree of professional tensions between scientific groups, they were also resonant of wider concerns felt in Ireland that a central government located in distant London was proving inattentive to Irish needs. His articulation of this in a nationalist-minded newspaper ensured that he addressed a receptive audience who might adapt the ambiguity of science's function within relief practice into a trope with which to articulate wider apprehension regarding centralised approaches to Ireland.

Such public critiques of the impracticalities of scientific advice placed nutritional science in danger of becoming perceived as synonymous with political inefficacy. Tellingly, Reverend Richard Walsh of Headford, Co. Galway, returned recommendations dispatched to him as a measure not only of his lack of confidence in the Commission but also of his horror at governmental indifference towards the want and distress of the Irish nation. ${ }^{47}$ Unsurprisingly, the Commission's activities soon generated anger within the nationalist press. By November, The Nation was calling for all official recommendations to be rejected as, if anything, the decomposition of the potato seemed to be accelerated by them. ${ }^{48}$

Journalistic hostility to official activities accentuated in December 1845 when the Commission circulated a nationwide questionnaire requesting information on the spread of the blight. It seemed to many critics that, although months had now passed, all Kane and

\footnotetext{
43 NAI, RLFC2/Z14434.

44 NAI, RLFC2/Z16624.

${ }^{45}$ NAI, RLFC2/Z14888; RLFC2/Z15316.

46 'The Potato Malady', Freeman's Journal, 31 October 1845, 3.

${ }^{47}$ NAI, RLFC2/Z15866.

${ }^{48}$ Nation, 1 November 1845, 36.
} 
his colleagues had achieved so far was to meet and theorise, rather than undertaking more practical tasks such as collating information regarding the extent of loss of the potato crop, when scarcity was likely, the state of the food markets and levels of alternative foodstuffs available in Ireland. This predicament intensified hostility towards the Commission, as is evident in the Freeman's Journal's declaration that 'this negligence - this apathy - this carelessness of the obligations of humanity is so shameful, and we have no doubt that the government will yet be made to feel that this is so'. ${ }^{49}$ The Cork Examiner, meanwhile, insisted that the government were 'mocking the Irish' with this 'unaccountable delay', pronouncing that 'our rulers would lavishly squander public money on itinerant "Commissioners" who came here to abuse us, but are deaf to our cries for bread'. ${ }^{50}$ At a meeting in Mayo held in January 1846, later recorded in the Freeman's Journal, one speaker announced that 'the learned pundits, if anything, had recommended a course of action which was the complete opposite of that which would have been wisest', and that 'such is the dependence to be placed on the theories of those self-sufficient gentry, who take upon themselves so dogmatically to point out the causes of and the remedies for the visitations of Providence'. ${ }^{51}$ In all these examples, nutritional science itself became deeply entangled within a wider web of simmering anti-Union sentiment and depicted as an integral and illustrative facet of British political neglect.

As the cost of the Commission became apparent in the summer of 1846, anger peaked, as did attacks on the utility of nutritional science. Despite a costly financial outlay, it seemed to many critics that all the expense surrounding the Commission had achieved was to confirm that the potato crop was failing. Although Lindley was acknowledged with possessing a profound knowledge of vegetable physiology, The Nation stated 'we defy anyone to point out a single physiological reason advanced on the subject by him, or even the smallest exhibition of scientific knowledge, from the appearance of the celebrated manifestoes of the Potato Commissioners to the present day'. The contributor also suggested that Lindley 'has scarcely advanced a single opinion on the disease which he has not renounced at a subsequent period'. ${ }^{2}$ By November, the Tuam Herald was describing the so-called 'Potato Commission' as 'the greatest farcical humbug ever got up even in Ireland' and promptly renamed it 'The Commission for the Destruction of Potatoes' on the basis that 'it is a notorious fact that in every instance where the direction of the Commissioners was followed, the potatoes were utterly destroyed' ${ }^{53}$ Clearly, some months into the operations of the Commission, attitudes had evolved from scepticism to outright rejection.

The approach of the Scientific Commission demonstrates the prominence of chemical and nutritional theory during the 1840s in official circles. The Famine presented Liebig's disciples with an opportunity to publicly demonstrate social prowess and to promulgate a sense of chemistry's social usefulness. The attempted conversion of diseased potatoes was an expression of the excitement and confidence placed in contemporary food investigations. The nutritional quality of the potato diet had been confirmed, to some surprise, and it could now be hypothesised that the Irish peasantry could subsist once they had salvaged the nutritional goodness from their diseased crops. On one hand,

\footnotetext{
49 'The Government Commission: The Potato Disease', Freeman's Journal, 19 December 1845, 2.

${ }^{50}$ Cork Examiner, 29 December 1845, 2.

51 'The Potato Disease', Freeman's Journal, 15 January 1846, 2.

52 'The Potato Crop', Nation, 8 August 1846, 16.

53 'Dr Kane on the Potato Commission', Tuam Herald, 7 November 1846, 2.
} 
reactions against the Commission's scientific suggestions represented scepticism towards medical science's practical applicability. Yet science's entanglement with political critique simultaneously undermined public perceptions of the discipline, whilst its solutions became publicly castigated as further evidence of governmental neglect, providing antiUnion voices with a rich resource with which to articulate political critique. The most that officially sanctioned research into the chemical constitution of the potato seemed to many to have proven was what the Irish had instinctively known all along: that they could subsist healthily on the potato. Although this appeared as a momentous revelation to chemical scientists, from the perspective of the Irish peasant and critics, the financial costs incurred discovering what was inside a potato and how to extract its elements might have been better spent by the state on providing food for an increasingly destitute population.

\section{Replacing the Potato}

The onset of widespread famine-related diseases during the winter of 1845-6 suggested direct connections between innutritious diet and epidemic disease. It also became increasingly apparent that diseased potatoes, even if peasants had managed to extract their nutritional content, were entirely unsuitable for consumption. Throughout late 1845, prominent Dublin physician Dominic Corrigan had written to the Scientific Commission warning that the consumption of extracted starch encouraged epidemic disease by lowering nutritional standards, although his advice was ignored ${ }^{54}$ His stance was intended to add weight to arguments for a more efficient relief policy involving supplying food. Yet by winter, doctors were observing that patients who had consumed diseased potatoes were contracting symptoms including rigors, hot skin, abdominal pain, diarrhoea and swollen muscles. ${ }^{55}$ Initially, these observations seemed to suggest the existence of an entirely new form of gastro-enteritis. ${ }^{56}$ However, in April 1846, the Dublin Hospital Gazette noted that symptoms shared commonalities with the land scurvy recently witnessed in Indian famines. Such discoveries became utilised as evidence that the government needed to assist the Irish population in locating an alternative food supply. ${ }^{57}$

In the meantime, Corrigan had been aggressively reiterating his views, published in The Lancet fifteen years earlier, on the correlation between innutritious diets and epidemic disease, a connection not universally agreed upon. Alternative explanations for 'Famine Fever' instead emphasised associations between poverty and fever, and the role of atmospheric or electrical phenomena in disease generation. ${ }^{58}$ Corrigan republished his findings in pamphlet format in 1846 to warn of the strong likelihood of fever striking again. To solidify his point, within his On Famine and Fever Corrigan detailed the experiences of over one hundred years of Irish famines, concluding that regardless of season or climate, each time a fever epidemic had struck Ireland, famine had been present. Cynically, he suggested that those who persisted in drawing linkage between filth and fever did so to provide justification for withholding the most suitable form of aid - food - to the starving. ${ }^{59}$

${ }^{54}$ NAI, RLFC2/Z14518.

55 'Symptoms Produced by Eating Diseased Potatoes', Dublin Hospital Gazette, 23 (1846), 166.

56 J.D. O'Brien, 'Cases of a Peculiar form of Gastro-enteritis Resulting from the Use of Diseased Potatoes', Dublin Hospital Gazette, 24 (1846), 184-5.

${ }^{57}$ M.J. McCormack, 'A Case of Land Scurvy Produced by Eating Diseased Potatoes', Dublin Hospital Gazette, 29 (1846), 263-8.

${ }^{58}$ Geary, 'Late disastrous epidemic', op. cit. (note 2), 49-50.

${ }^{59}$ Dominic J. Corrigan, On Famine and Fever (Dublin: J. Fannin, 1846). 
Corrigan's ideas were invariably dismissed as conjecture, and responses insisted that fever also recurred in times of plenty ${ }^{60}$ Yet Corrigan became notably prominent during the Famine, being appointed as a key member of the Central Board of Health, which was, due to changes in patterns of Famine Fever, established in March 1846, disbanded in August and reappointed in February 1847. Hence, he became well positioned to project his interpretation of the relationship between fever and famine, and eagerly employed ideas drawn from nutritional science to emphasise his views. The Board also consisted of esteemed Dublin medical practitioner Philip Crampton, Robert Kane and two civil servants, Randolph Routh and Edward Twistleton. ${ }^{61}$ This group attempted to instigate a more practical application of scientific theory than the Scientific Commission had achieved.

Both the Commission and the Board made use of Liebigian science as a shared frame of reference, formulating advice upon notions that the potato contained all of the essential nutritional elements which now had to be obtained separately in combinations of meats, vegetables and grains. Yet for the Board only a scientifically based varied diet could relieve the impact of famine, a perspective expressed in their arguments that ignorance of this tenet had led voluntary relief providers including the Quakers to make erroneous decisions. Rice, for instance, had been dispersed on the basis that it acted as a sole article of food in oriental nations. Yet the Board publicly insisted that rice was not consumed alone anywhere, always being instinctively prepared with vegetables, oil, butter, meat or fish to add important nutritional elements which it did not itself contain. Supposition that bulks of rice would supply the missing quantity required by the Irish poor were thus presented as mistaken. Rice, the Board maintained, would certainly swell into a visible mass, yet this mass contained a smaller proportionate quantity of nutriment than potatoes. ${ }^{62}$

This critique of unofficial food relief programmes was a clear attempt at articulating the superior nature of dietetic knowledge derived from laboratory analysis and experimentation, and at carving out an important social function for nutritional knowledge in Ireland. Importantly, the stance of the Board challenged older assumptions regarding Irish diet based upon physiological differentiation. Unlike Johnson and Foster's earlier accounts, discussion of food focused less upon judging the quantity of potatoes consumed in Ireland and more upon ensuring that nutritional quality would underpin wider processes of dietary reform and modernisation. It is in this context that the Board looked favourably towards Indian meal and oatmeal as substitutes as these foodstuffs were seen to have an immediate influence on dietetic health as well as the potential to permanently modernise Irish food systems if popularised, a stance which further reveals the forging of synergies between scientific and politico-economic agendas. Certainly, this perspective was remarkably evident when the Board optimistically claimed in an official report that the introduction of meal had transformed how the Irish thought about food. On this matter, they claimed:

It has often been desired, that the people of Ireland could be induced to turn from the potato to grain as their food, as tending to produce improvement in their habits, and as rendering them less liable to suffer from periodic famines. All attempts to effect this have hitherto failed. However, the knowledge that they have now acquired of the very superior nutritious qualities of oatmeal, and its price continuing to bear

${ }^{60}$ Geary, 'Bloody flux', op. cit. (note 2), 75.

61 Geary, 'Late disastrous epidemic', op. cit. (note 2), 51.

${ }^{62}$ Report of the Commissioners of Health, on the Epidemics of 1846 to 1850, Reports of Commissioners, Commons, 1852-3, Cmd. 1562, vol. XLI, 19-21. 
such a relation to the cost of potatoes, as to render its consumption often more economical than that of the potato, will, it would seem to us, eventually and certainly lead to the desired end. ${ }^{63}$

This statement clearly demonstrates a faith in the good that could result once the short-term implications of the potato blight had passed: a change in crop culture would simultaneously protect from future famines and promote changes in social and individual behaviour.

In autumn 1845, Robert Peel purchased $£ 100000$ worth of Indian meal from America and sales commenced from March $1846 .{ }^{64}$ The introduction of Indian meal initially generated enthusiastic responses. National newspapers printed recipes for tasty puddings and bread made from Indian corn. Not only was it described as highly nutritious for humans, but it was also noted to be an admirable food for fattening pigs and oxen, whilst dogs were reported to relish it. ${ }^{65}$ In reality, however, supplying the public with scientifically defined food supplies was a process punctuated with practical difficulties, and members of the Board became increasingly critical of indoor relief policies. Poor Law Unions were allowed to substitute potatoes for alternative foodstuffs from $1846 .{ }^{66}$ By 1848 only three out of 140 workhouses were reported to be serving neither type of meal, whilst fifty-four served a mixture of oatmeal and Indian meal, the remainder serving one or the other. ${ }^{67}$ However, these statistics fail to account for problems in preparing dishes containing meal. When meal was introduced into the South Dublin Union Workhouse in April 1846, for instance, the baker had no comprehension of how it could be mixed with flour to produce bread, a scenario which implied the pitfalls of a policy that simply provided food without instructions on how to cook it in a country primarily accustomed to preparing potatoes. ${ }^{68}$

These issues challenged idealised images of the harmonious compatibility of culinary practice and nutritional theory. Revealingly, in May, members of the South Dublin Union Relief Committee publicly asserted that allocated portions of a pound of bread made from meal and three pints of porridge fed only two people rather than six. On this subject, one member stated, "we do not think that sixteen ounces of food, the allowance given by the South and by the North Union Committees, has been recognised by physiologists as sufficient for the healthy sustenance of an adult man', adding that the economic savings were not enough to justify keeping pauper populations in a precarious balance between healthy and diseased existence. ${ }^{69}$ A fortnight later, the Lord Mayor of Dublin toured the city's workhouses, tasting the dishes on offer. Paupers complained to him that they would prefer bread to porridge, as the latter played havoc with their stomachs. ${ }^{70}$ Hence, nutritional theory became presented as failing to account for individual bodily reactions to

63 Ibid., 25.

64 James S. Donnelly JR., 'Famine and government response 1845-6', in Vaughan (ed.), op. cit. (note 30), 272-85: 278.

65 'How to Convert Indian Corn into Food', Freeman's Journal, 21 February 1846, 4; 'Indian Corn', Freeman's Journal, 28 February 1846, 1.

66 Twelfth Annual Report of Poor Law Commissioners, Reports of Commissioners, Commons, 1846, Cmd. 704, vol. xix.1, 25.

${ }^{67}$ Data collated from Returns from County Gaols and Workhouses in Ireland of Daily Diet allowed to AbleBodied Men, Accounts and Papers, Commons, 1847-8, 486, vol. liii.

68 'South Dublin Union', Freeman's Journal, 18 April 1846, 4.

69 'Pauper Rations', Freeman's Journal, 13 May 1847, 2.

70 'South Union Relief Committee', Freeman's Journal, 27 May 1847, 4. 
new dietary articles, a discourse which formed an important part of critical public coverage of this aspect of relief practice.

In response to concerns regarding indoor relief, the Board intensified its arguments regarding the provision of cooked food, a step which suggests increasing divergence from official relief policies amongst medico-scientific advisors in Ireland. ${ }^{71}$ Unlike the Commission, the Board increasingly distanced itself from official relief strategies as the realities of Famine became ever more apparent, and as nutritional science became increasingly critiqued in public domains. With workhouses becoming ever more swamped and epidemic disease rapidly spreading, the Board increasingly articulated discontent with the limitations of legislation intended to meet the demands of famine, in one instance asserting that institutionalisation was a greater evil then allowing the poor to fend for themselves in the community. ${ }^{72}$ This was probably an exaggeration intended to justify arguments for a more interventionist form of state relief, but it did raise pertinent questions regarding whether peasants were better off in institutions or in the community. Meal supplies in the latter were often so poor that the consumption of diseased potatoes continued. A limited understanding of how to prepare and cook meal was just as prevalent in the community as it was in workhouse kitchens. Initially, Indian meal had been imported un-milled, and was not always subsequently ground sufficiently by millers, resulting in widespread illness. ${ }^{73}$ The Board insisted that if meal was insufficiently cooked then a full supply of nutriment failed to be provided, predisposing the community to dysentery and diarrhoea, an argument which further justified arguments regarding linkage between dietary deficiency and disease. ${ }^{74}$ As the dissemination of recipes appeared to be proving ineffective, the Board argued that closer regulation of the Irish poor's nutritional health was necessary if the tide of epidemic disease was to be halted, a process requiring scientific guidance. Hence, the Board began to encourage an official relief policy involving the provision of cooked food as part of outdoor relief. Only by doing so could consumption be nutritionally regulated and appropriate safeguards against disease established.

Overall, the Central Board of Health strove to bridge the chasm between nutritional theory and nutritional practice. As well as promulgating awareness of connections between disease and innutritious diet, the Board stressed the importance of food quality as a means of enabling Irish modernisation, an approach which displaced discourse on the physiological ramifications of a bulky potato diet and which asserted the authority of new forms of nutritional science. The Board came under less public criticism than the Commission had done as, if anything, its members increasingly challenged the inefficacies of government policy. Nonetheless, its medical representatives Corrigan and Crampton simultaneously publicly participated in wider politico-economic visions of promoting permanent societal change in Ireland through dietary transformation. Drawing upon narratives of Irish improvement, they defined a move away from a mono-crop existence as compatible with nutritional science although their efforts to achieve this were impeded by the intensity of famine.

\footnotetext{
71 'Precautions against Pestilence', Freeman's Journal, 28 April 1847, 2.

72 Geary, 'The late disastrous epidemic', op. cit. (note 2).

73 Donnelly JR., 'Famine and government response 1845-6', op. cit. (note 64), 279-80.

74 Ibid., 21.
} 


\section{Soup Controversies}

The Board's aspirations for adequate relief policies were thwarted when the government did embark on dispersing cooked food. Throughout 1846, overwhelming applications for indoor relief encouraged the government to open nationwide soup kitchens, despite this policy being contrary to their pervasive laissez-faire ideologies. The Temporary Relief Act instigated the setting up of these establishments. ${ }^{75}$ In 1847, the government consulted Alexis Soyer, famed French chef of the Reform Club, and quickly dispatched him to Dublin where he began constructing a network of kitchens. Cooked food provision was approved of by the Board's members who were becoming ever more exasperated by observations of people devouring raw meal. ${ }^{76}$ Yet the scheme was immediately stricken with controversy, not least because the very idea of the soup kitchen was closely associated with the stigma and social degradation of pauperism, as had become evident during international attempts to establish them on Count Romford's model during earlier decades. $^{77}$

From the onset, the grandiose ceremonial opening of the scheme caused consternation. The Freeman's Journal expressed nationalist fury at the opening of Dublin's first soup kitchen as the Union Jack was 'flaunted from the top of the soup kitchen... proclaiming to the Heavens the degradation of our provincialism, but unfolding a tale, as it flaps in the listless air, of a union with England brought about by force, stained by corruption, cemented in blood, and now consummated in famine'. Here, the soup kitchen became perceived as emblematic of the extension of an unwelcome foreign power into Ireland, symbolising a lack of sensitivity to the needs of a vulnerable, subjugated populace. ${ }^{78}$ For the Freeman's Journal, the public feeding of members of the poor at the scheme's opening ceremony was an inappropriate, but telling, articulation of English attitudes towards the Irish poor. 'Five shillings each to see paupers feed'!, exclaimed the newspaper, 'five shillings each to watch the burning blush of shame chasing pallidness from poverty's wan cheek! - five shillings each! When the animals at the Zoological Gardens may be inspected at feeding time for sixpence' ${ }^{79}$ Hence, despite their ideals, soup kitchens became condemned as emblems of Imperial expansion by nationalist voices. The very act of eating and digesting food in these establishments carried meanings of subjugation to an Imperial power, of colonial unjustness and inhumane treatment. Soup kitchens were presented not as benevolent structures, but instead as sites established to ease the conscience of those in power; buildings masquerading as expressions of British kindness but in reality serving concoctions devoid of nutritional or palatable value. The physical act of consuming food there carried symbolic meanings relating to subjugation and a shunning of responsibility to care for starving citizens.

These issues permeated the objections of medical authorities who took issue with the manner by which nutritional science was being publicly presented in such schemes, an approach which also allowed them to adopt a more detached stance from official relief policies. Allegations of the dishonesty and public spectacle of Soyer's soups coloured professional critiques of the kitchens. While his Dublin kitchen was under construction,

\footnotetext{
75 Kinealy, op. cit. (note 10), 120-1.

76 'The Rations for the Poor: Spread of Fever', Freeman's Journal, 19 May 1847, 2.

77 See Fritz Redlich, 'Science and Charity: Count Rumford and his Followers', International Review of Social History, 16 (1971), 184-216.

78 'The Soup Fete: Degradation Consummated', Freeman's Journal, 10 April 1847, 2.

79 'Finale of a Cook's Triumph', Freeman's Journal, 14 April 1847, 2.
} 
Soyer had penned a booklet entitled The Poor Man's Regenerator which recorded his economical recipes intended to assist the Irish poor. ${ }^{80}$ Soyer proudly proclaimed to have personally discovered that existing soup providers were ignorant of the nutritional quality of their ingredients. Proper seasoning, Soyer maintained, was necessary to restore and strengthen the digestive organs. ${ }^{81}$ However, Soyer would have been better positioned to publish such strong claims had he actually been equipped with an understanding of scientific cookery. Certainly, for many medical men the digestive organs of famine-stricken peasants required more than the addition of herbs to their soups, as Soyer recommended. Critical medical professionals in both Ireland and Britain spotted Soyer's precarious comprehension of the principles of food science, and angrily denounced his ideas as fraudulent and his soups as deficient. Prestigious Edinburgh doctor James Simpson wrote to Henry Labouchere, Chief Secretary of Ireland, condemning Soyer. Drawing upon Liebigian animal chemistry, Simpson asserted that most of Soyer's soups contained no meat, despite meat having been scientifically proven to contain more nutriment than vegetable products. Reciting Liebigian theory, he recommended that soup should not be provided unless prepared using valid scientific principles. ${ }^{82}$

In similar fashion, The Lancet derided Soyer's recipes as 'soup quackery' and as 'soups of pretence... taken by the rich as a salve for their consciences' as part of 'a spasmodic feeling of benevolence'. The journal noted that other clubs, committees and relief associations had dispatched food without any boasting or ostentation, in sharp contrast to the government's public spectacle. The Lancet then undertook a thorough chemical analysis of the content of each soup, dismissing some of its contents - turnip parings, celery tops and salt - as items not even describable as food. Soyer's soups were determined to contain less than three ounces of solid aliment per quart, despite nutritional chemistry stating that a healthy individual required between twelve to fourteen ounces. On this, The Lancet sardonically warned that 'organic chemistry will not, we fear, bend to the receipts of the most miraculous cookery book'.

Continuing its scathing attack, The Lancet complained that both Soyer and the government were inaccurate in assuming that a bulk of water would compensate for a deficiency of solid aliment, as:

No culinary digestion, or stewing, or boiling, can convert four ounces into twelve, unless, indeed, the laws of animal physiology can be unwritten, and some magical power be made to reside in the cap and apron of the cook for substituting fluids in place of solids, and aqua pura for solid aliment, in the animal economy.

The journal concluded by declaring that although the public mind had been satisfied by developments in relief provision, this was unlikely to extend to the public stomach. 'Marquises, and lords and ladies, may taste the meagre liquid, and pronounce it agreeable to their gustative inclinations', claimed the journal, 'but something more than an agreeable titillation of the palate is required to keep up the manufactory of blood, bone and muscle, which constitutes the strong healthy man'. ${ }^{83}$

What angered The Lancet the most was an apparent misappropriation of accumulated scientific knowledge, the misrepresentation of which was feared to be strengthening public associations of food chemistry with deficient relief policies. At stake in the

\footnotetext{
${ }^{80}$ Ruth Cowen, Relish (London: Phoenix, 2006), 127.

81 Alexis Soyer, Soyer's Charitable Cookery (Dublin: Hodges and Smith, 1848), 11-2.

82 James Simpson, On the More Effective Application of the System of Relief by Means of Soup Kitchens (London: Whittaker and Co., 1847).

83 'Editorial', Lancet, 49 (27 February 1847), 232.
} 
debates regarding the nutritional quality of Soyer's soups were important questions of medical respectability and professionalism, as well as ownership of knowledge. Certainly, The Lancet's accusation of quackery was not accidental. In a period when medicine was professionalising, public articulations of inaccurate scientific knowledge were potentially damaging, especially when seemingly sanctioned by a London-based government. Furthermore, the interest aroused by the Famine meant that relief practices were now publicly discussed internationally. The medical profession had been notably quiet when the Scientific Commission had dispersed publicly challenged advice at the commencement of the Famine. Then, state policy was at least attempting to make good use of analytical knowledge, even if in a misguided fashion. Yet, two years later, the government appeared to be relying upon nutritional knowledge whom they castigated as a medical charlatan - a development with potential ramifications to public images of professional respectability. Hence, the idea that nutritional science had in any way informed soup kitchen schemes was staunchly dismissed, while the forms of knowledge underpinning soup provision were denigrated as false. After all, this was the sort of 'quack' activity which medical reformers were eager to distance themselves from. Medical critics in Britain articulated instead the prowess and social utility of 'proper' nutritional science, although it is notably remarkable that the Dublin Medical Press, then the Irish equivalent of The Lancet, remained mostly silent on such issues despite normally being outspoken.

Importantly, these debates reached far beyond the pages of the medical press. Even Queen Victoria's doctor Sir Henry Marsh suggested within a widely distributed pamphlet that soup was an unhealthy, dangerous relief mechanism, maintaining that semi-liquid diets could only maintain the health of children and sedentary adults. The labourer's food, Marsh insisted, should be partly solid as digestion requires mastication and insalivation. Liquid soups, on the contrary, were naturally digested too quickly, producing hunger and debility. To confirm this point, Marsh argued that the habit of eating the 'bone of the potatoe' had in fact long fulfilled these bodily requirements as it had necessitated a slow digestion of a solid substance. For Marsh, 'the consideration of the diet best calculated to uphold his [the labourer's] strength and maintain his health is at all times one of the highest national importance - at the present time, and in the existing disastrous state of the country, it is one which claims the utmost amount of attention, scientific and practical, which can be devoted to it'. Yet, for Marsh, official responses dangerously violated established scientific laws, as expressed through statements which reasserted the validity of 'proper' scientific knowledge. ${ }^{84}$ The final publication related to the soup kitchen controversy was a report commissioned by the Royal Dublin Society to examine Soyer's soups, compiled and penned by prominent Irish chemist John Aldridge. ${ }^{85}$ Aldridge analysed the nutritive values of the soups on offer in Soyer's soup kitchen, comparing these with analytical chemistry's dietary laws. Within his report, Aldridge praises only one of Soyer's soups, as it contained fish. Yet Aldridge concluded by asserting that, in order to sustain healthy animal life, it was necessary to combine flesh, seeds and vegetables in a bulky preparation of food proportionate to the capacity of the digestive organs, rather than by the methods employed by Soyer.

Notably, like many contemporaries, Aldridge perceived the onset of blight as a suitable opportunity to generate Irish industriousness, which suggests that such visions were not discarded despite the immediate urgency of providing short-term solutions to Famine by

${ }^{84}$ Henry Marsh, On the Preparation of Food for the Labourer (Dublin: James McGlashan, 1847).

${ }^{85}$ Cowen, op. cit. (note 83), 130. 
1847. Revealingly, within his report, Aldridge argued that professional forms of scientific knowledge, rather than Soyer's interpretation, had much to offer the Irish situation in both the short term and long term. He noted that carnivorous animals living on highly concentrated food tended to be energetic, whilst herbivorous animals, tending to eat more gradually, were sluggish and idle. Aldridge insisted that if Ireland's population was fed in a similar manner to cows and sheep, then industrial exertion could never result. Yet the Irish poor were considered by him to have been even worse fed than cattle for decades, as hay was a far more concentrated food than potatoes. ${ }^{86}$ Thus, in contrast to the dominant iconography of the Famine which focused upon the skeletal, starved rural peasant, medico-scientific communities continued to depict a potentially empowered peasant invigorated by a precise comprehension of nutritional science, although this was achievable only if he was shielded from false forms of nutritional knowledge. Hence, Aldridge, like many contemporaries, remained eager to position nutritional science as a field with potential long-term benefits to Ireland, provided that professional forms of scientific knowledge based upon analysis and deduction were applied. Despite this, however, a general distancing of the medical profession from state relief policies occurred in both Britain and Ireland which contrasted sharply with an earlier willingness to collude with state activity. By 1847, nutritional science's positioning within official policy had become contested and complicated, a scenario which structured shifts in how scientists interested in nutrition publicly presented themselves.

\section{Conclusions}

This article has demonstrated that medico-scientific ideas relating to nutritional health played a visible role in state-sponsored relief policy, a consequence of a strong socially active dietetic science having been developed. During the Famine, various scientists acted as authoritative voices on substitute foodstuffs and the nutritive properties of soups. By doing so, these scientists were able to engage with wider debates about the reform of Irish society, a development that suited the social agenda of organic chemistry more generally. Yet, associations were fostered between nutritional science and the shortcomings of central policy among Irish lay communities. Towards the end of the Famine, even leading Irish medical figures including William Wilde were forced to admit that medico-scientific intervention had failed to live up to its aspirations, having been received with public hostility, and its ideas having been misappropriated within official relief strategies.

86 John Aldridge, On the Comparative Nutritive and Pecuniary Value of Various Kinds of Cooked Food (Dublin, 1847). 